\title{
Devassa da vida privada dos índios coloniais nas vilas de El Rei
}

\author{
MARIA LEÔNIA CHAVES DE RESENDE*
}

\begin{abstract}
Resumo: Este artigo trata da vivência de índios e/ou seus descendentes, de diversas procedências étnicas que desterrados de suas aldeias, passaram a viver nas vilas de Minas Gerais, no século XVIII.

Abstract: This articles deals on the trajectory and the ways of life of the Indians and/or their descendants of different ethnical origins who, stalked into the wilderness by explorers, came to live in the small villages and towns of Minas Gerais in the eighteenth century.
\end{abstract}

Palavras-chave: Etnohistória indígena. Minas Gerais colonial.

Key words: Native ethnohistory. Minas Gerais colonial period.

\section{Vícios, erros, abusos e escândalos}

Comissário da Santa Cruzada, os. Reverendo Domingos Luiz da Silva, Vigário Colado na Igreja Matriz das Catas Altas proclamava, em 1733, um edital da Visitação Diocesana à Comarca do Rio das Mortes. Com esse expediente, promovia mais uma visita pastoral nos rincões de Minas para fiscalizar a vida dos fregueses e punir os transgressores. Sua intenção era contundente: desterrar "os vícios, erros, abusos e escândalos", fazendo "muitos serviços a Deus e a Nossa Senhora, em grande bem espiritual e temporal de suas ovelhas". ${ }^{1}$ Dentro desse espírito, reafirmava o principal objetivo das visitas eclesiásticas: manter a vigilância sobre os paroquianos, apontando os abusos e definindo as punições.

* Doutora em História Social da Cultura/UNICAMP. Professora e Coordenadora do Curso de Pós-Graduação em História de Minas Gerais, XVIII-XIX/DECIS/Universidade Federal de São João del-Rei. E-mail: leonia@ufsj.edu.br.

1 ACM (Arquivo da Cúria de Mariana), Livro n. 31 (Testemunha), Devassa, (1733).

Estudos Ibero-Americanos. PUCRS, v. XXX, n. 2, p. 49-66, dezembro 2004 
As visitas pastorais ou diocesanas - como ficaram conhecidas - seguiam, assim, o mesmo procedimento. Após a chegada triunfal do visitador - em geral um bispo ou seu preposto - celebrava-se uma missa solene na matriz onde se anunciavam as razões da visita. Cumprindo o cerimonial, o escrivão lia o edital em que todos os fregueses eram conclamados a denunciar, no prazo de vinte e quatro horas, sob os ouvidos atentos do visitador, os "pecados públicos e escandalosos". O rol das infrações, cerca de quarenta delitos, publicados na missa conventual, tinha como princípio nortear a conduta que se esperava dos moradores de cada capela. ${ }^{2}$

Das ofensas contra os princípios da Igreja católica apontadas no edital emergia toda a natureza de infrações: do gravíssimo crime de heresia ou apostasia à blasfêmia contra a honra de Deus, da Virgem ou dos Santos, do uso da feitiçaria, de adivinhações ou da invocação do demônio à simonia e sacrilégio. Dos crimes contra a família pululavam o adultério, concubinato, incesto, alcouce, prostituição e também não faltaram violações de outra natureza como os pecados nefandos ou bestiais, a usura, ou delitos corriqueiros como o descumprimento dos preceitos quaresmais de não comer carne ou faltar às missas dominicais. ${ }^{3}$ Todas infrações eram, então, proporcionalmente punidas. ${ }^{4}$

Segundo as Constituições Primeiras do Arcebispado da Bahia, as visitas atentavam para o "governo espiritual e temporal", cuidando da "reverência do culto divino, a reforma dos costumes

2 Ver, por exemplo, o edital da visita na Comarca do Rio das Mortes. ACM, Livro n. 31, Devassa, (1733).

3 Neste edital, aparecem arrolados 40 delitos. ACM, Livro n. 31, Devassa, (1733). Torres-Londoño apresenta essas infrações em seis categorias: 1) faltas contra a fé, como heresia, apostasia e feitiçaria; 2) contra a Igreja e a vida cristã, como não assistir missa aos domingos, comer carne, não pagar o dízimo, viver excomungado por mais de um ano; 3) contra a moral sexual e o matrimônio, como bigamia, consentimento dos pais que as filhas "fizessem mal de si", sodomia, amancebamento com escândalo e a má vida que os esposos davam às esposas; 4) faltas cometidas pelos sacerdotes, como solicitação, negligência na administração dos sacramentos, injúrias; 5) faltas econômicas, como usura; 6) contra a visita, por intimidar testemunhas. TORRES-LONDOÑO, Fernando. A outra família. Concubinato, igreja e escândalo na colônia. São Paulo: Loyola, 1999, p. 144.

4 As penas íam das mais brandas, restringidas à recusa dos sacramentos e na proibição de assistir ao culto, às severas admoestações do Ordinário. Aos reincidentes do pecado, particularmente no caso de concubinato, punia-se com a separação do casal, sob pena de excomunhão em 24 horas, seguido da expulsão da comarca, recorrendo, se necessário, ao braço secular. As visitas eclesiásticas impunham a multa de $3 \$ 000$ para cada um, na primeira vez, dobrado o valor na reincidência e triplicado, em terceiro lapso. A prisão ou excomunhão também foi recurso comum para os que reincidiam pela quarta vez. FIGUEIREDO, Luciano Raposo de A. Barrocas famílias: vida familiar em Minas Gerais no século XVIII. São Paulo: Hucitec, 1997. 
e a extirpação dos pecados". ${ }^{5}$ Para dar conta disso, a visita pastoral deveria, por meio de uma devassa eclesiástica, reconhecer os transgressores em seus "abusos e erros" e, então, proceder a "emenda", impingindo o temor àqueles que ousassem não se submeter aos preceitos da Igreja católica. Obrigados a denunciar àqueles que incorriam nesses "pecados", os paroquianos acabaram produzindo uma enxurrada de delações. Daí, não raras foram as queixas dos que reclamavam de terem sido acusados injustamente. Tentando contornar essa situação - seja pela cumplicidade entre muitos fregueses tecida no cotidiano ou pela tentativa de envolver o acusado por mera vingança - exigia-se dos denunciantes "certa sabedoria ou fama pública", o que implicava o fornecimento de várias dados sobre o denunciado, como nome, estado, cor, local da moradia, nome dos cúmplices bem como as circunstâncias que permitiram tal informação. $\mathrm{O}$ acusado deveria, então, comparecer diante do visitador para assinar o termo de culpa e pagar uma multa. Como considerou Luciano Figueiredo e Caio Boschi, as visitas pastorais transformaram-se em uma "pequena inquisição" que desencadeou um verdadeiro processo persecutório em Minas. ${ }^{6}$

Circunscrevendo as comarcas, os tentáculos da Igreja rondaram Minas, aprisionando, em suas malhas, os índios coloniais que foram envolvidos, ao longo do séc. XVIII, em 767 denúncias nas devassas eclesiásticas. Incorrendo em muitas dessas infrações, os índios coloniais, dispersos por toda a Minas, acabaram por registrar sua maneira de lidar com a ordem colonial, ao protagonizarem muitas daquelas pequenas histórias do dia-a-dia, registrando fragmentos de si mesmos, de seu tempo, de suas práticas e vivências.

Torres-Londoño, loc. cit., p. 142.

Sobre as devassas, como ficaram conhecidas as visitas pastorais ou diocesanas, ver Francisco Vidal e COSTA, Iracy Del Nero da. Devassas nas Minas Gerais do crime à punição. In: Anuário de Estudios Americanos, Sevilha, tomo 39, 1982; SOUZA, Laura de Mello e. As devassas eclesiásticas da Arquidiocese de Mariana para a história das mentalidades. Anais do Museu Paulista, v. 33, 1984; FIGUEIREDO, Luciano Raposo A. Segredos de Mariana: pesquisando a inquisição mineira. Acervo. Rio de Janeiro, v. 2, n. 2, jul./dez.1987, p. 1-34; BOSCHI, Caio César. As visitas diocesanas e a inquisição na colônia. Revista Brasileira de História. São Paulo, v. 7, n. 14, 1987 e Torres-Londoño, loc. cit., p. 131-157. 
Quadro 1

Vilas/Região/Ano das devassas ${ }^{7}$

\begin{tabular}{|c|c|c|}
\hline Vilas/Comarca & $\begin{array}{c}\text { Quantidade/ } \\
\text { Denúncias }\end{array}$ & Data \\
\hline Airuoca (RM) & 14 & $1730,1738,1756,1763$ \\
\hline Baipendi (RM) & 60 & $1738,1749,1756,1760,1763,1765$ \\
\hline Borda do Campo (RM) & 26 & $1730,1733,1757,1764$ \\
\hline Campanha do Rio Verde (RM) & 15 & $1749,1756,1760$ \\
\hline Carijós (RM) & 26 & $1726,1730^{\star}, 1742,1753,1757$ \\
\hline Carrancas (RM) & 31 & $1738,1743,1749,1756,1760,1765$ \\
\hline Itaverava (RM) & 15 & $1730,1733,1754$ \\
\hline Lagoa Dourada (RM) & 1 & 1749 \\
\hline Lavras do Funil (RM) & 18 & 1736,1763 \\
\hline Paraopeba (RM) & 5 & $1731,1748,1749$ \\
\hline Pouso Alto (RM) & 10 & $1738,1749,1756,1757$ \\
\hline Prados (RM) & 26 & $1730,1733,1738,1749,1756$ \\
\hline Rio de Peixe (RM) & 2 & 1749 \\
\hline Santa Ana do Sapucaí (RM) & 2 & \\
\hline São João del-Rei (RM) & 31 & $\begin{array}{l}1730,1733,1738,1748,1756,1757,1759, \\
1760,1763\end{array}$ \\
\hline São José del-Rei (RM) & 14 & $1730^{\star}, 1733^{\star}, 1749$ \\
\hline Antônio Dias Abaixo (VR) & 21 & $1738,1742,1743,1743,1760$ \\
\hline Antônio Pereira (VR) & 6 & 1723,1726 \\
\hline Arraial de Passagem (VR) & 2 & 1764 \\
\hline Cachoeira do Campo (VR) & 12 & 1733,1764 \\
\hline Camargos (VR) & 8 & $1721,1724,1754$ \\
\hline Catas Altas (VR) & 12 & $1722,1730,1733,1737,1738,1757$ \\
\hline Congonhas do Campo (VR) & 51 & $1730^{*}, 1733,1738,1746,1749,1774,1776$ \\
\hline Furquim (VR) & 15 & 1730,1742 \\
\hline Guarapiranga (VR) & 32 & $1723,1726,1730,1737$ \\
\hline Inficionado (VR) & 7 & $1730^{*}$ \\
\hline Itabira (VR) & 7 & 1738 \\
\hline Itambé (VR) & 3 & \\
\hline
\end{tabular}

7 Das 767 denúncias contra os índios coloniais, 3 locais não foram identificados por ano. Onde consta asterisco é porque houve mais de uma denúncia neste ano. As comarcas estão assim indicadas: RM (Rio das Mortes); SF (Serro do Frio); RV (Rio das Velhas) e VR (Vila Rica). 


\begin{tabular}{|l|c|l|}
\hline \multicolumn{1}{|c|}{ Vilas/Comarca } & $\begin{array}{c}\text { Quantidade/ } \\
\text { Denúncias }\end{array}$ & \multicolumn{1}{|c|}{ Data } \\
\hline Itatiaia (VR) & 3 & 1731,1733 \\
\hline Ouro Branco (VR) & 3 & 1742 \\
\hline Ribeirão do Carmo (VR) & 20 & $1723,1726,1730,1751,1752,1753,1760,1775$ \\
\hline São Caetano (VR) & 12 & $1723^{\star}, 1730,1737,1754$ \\
\hline São Miguel de Piracicaba (VR) & 2 & 1759 \\
\hline São Miguel do Mato Dentro (VR) & 7 & $1727^{\star}, 1730^{\star}, 1743$ \\
\hline São Sebastião (VR) & 6 & $1721,1723^{\star}$ \\
\hline Sumidouro (VR) & 7 & $1723,1730,1737$ \\
\hline Vila Rica (VR) & 16 & $1726,1730,1731,1733,1734,1738,1744$ \\
\hline Caeté / Vila Nova da Rainha (RV) & 8 & $1733,1734,1738$ \\
\hline Curral del-Rei (RV) & 26 & $1734,1748,1759$ \\
\hline Mateus Leme (RV) & 3 & $1748^{\star}, 1754$ \\
\hline Morro Grande (RV) & 7 & $1730,1733,1737,1738,1759$ \\
\hline Pitangui (RV) & 39 & $1726,1727,1738,1748,1759$ \\
\hline Raposos (RV) & 1 & 1756 \\
\hline Sabará (RV) & 11 & $1731,1734,1738$ \\
\hline Santa Bárbara (RV) & 19 & $1733,1738,1743,1757$ \\
\hline Santo Antônio da Roça Grande (RV) & 6 & 1727 \\
\hline Santo Antônio do Rio Acima (RV) & 2 & \\
\hline Santo Antônio do Rio das Velhas (RV) & 5 & 1749 \\
\hline Santo Antônio do Rio das Pedras RV) & 3 & 1727,1734 \\
\hline São Gonçalo de Contagem (RV) & 10 & $1752,1754,1760,1763$ \\
\hline Arraial do Tejuco (SF) & 2 & 1752 \\
\hline Conceição do Mato Dentro (SF) & 5 & $1727^{\star}, 1738,1756,1759$ \\
\hline Serro Frio (SF) & 12 & 1734 \\
\hline Vila do Príncipe (SF) & 32 & $1726,1727,1738,1749,1750,1754,1756$, \\
\hline Total & & 1757,1759 \\
\hline
\end{tabular}

Fonte: ACM, Devassas de Mariana (1721-1800).

As visitas pastorais alçaram os lugares mais recônditos de Minas e, por meio das denúncias, revelaram a presença difusa dos índios coloniais, espalhados por tantas paragens, lugarejos e vilas. Isso certamente estava relacionado com a itinerância de muitos deles. Tal mobilidade, promovida seja pela fuga ou absenteísmo 
nos aldeamentos ou tanto quanto pela mera busca de outra sorte, foi um traço marcante do comportamento daqueles homens. Se Sheila Faria assinalou que a mobilidade espacial nas regiões de fronteira era uma das parcas estratégias dos homens pobres, os "andarilhos da sobrevivência", para burlar a pobreza, não é imponderável que a mesma lógica tenha prevalecido para os índios coloniais. ${ }^{8}$ E não só as devassas demonstram essa constante mobilidade dos índios coloniais mas também os processos matrimoniais. ${ }^{9}$

Uma outra questão a ser notada é a predominância das denúncias relativas aos índios coloniais na primeira metade do séc. XVIII. É possível que isso expresse mais que uma redução das denúncias - seja até porque ainda há livros a serem "redescobertos" nos arquivos - mas um sinal da "invisibilidade" que deve ter repercutido também na identificação de muitos deles nas devassas, tomados como mestiços e/ou pardos.

Quadro 2

Número de denúncias nas devassas / Década

\begin{tabular}{|l|c|}
\hline Década & Número de Denúncias \\
\hline $1721-1727$ & 118 \\
\hline $1730-1738$ & 283 \\
\hline $1742-1749$ & 100 \\
\hline $1750-1759$ & 104 \\
\hline $1760-1765$ & 95 \\
\hline $1774-1776$ & 3 \\
\hline S/D & 64 \\
\hline Total & 767 \\
\hline
\end{tabular}

Fonte: ACM, Devassas de Mariana (1721-1800).

8 FARIA, Sheila de Castro. Colônia em movimento. Fortuna e família no cotidiano colonial. Rio de Janeiro: Nova Fronteira, 1998, p. 102.

9 Dos 136 processos matrimoniais, 93 índios declararam o domicílio diferente do lugar de naturalidade, sendo que apenas 6 índios indicaram que a procedência continuava sendo a mesma da residência por ocasião dos banhos. 
Contracenando com os índios coloniais nos delitos apontados nas devassas eclesiásticas, tinham homens livres, escravos e forros. Os implicados envolviam até mesmo o próprio clero a quem o discurso moralizador da Igreja nem sempre tocou profundamente. 10 Vários padres foram denunciados, entre outras acusações, por terem "vida dissoluta" e "andarem" com as índias na Minas Gerais. Por serem acusados de concubinato com carijós ou bastardas, 24 padres, 2 clérigos "in minoribus" e 3 freis caíram nas redes das visitas.

Não seria outra a razão para o Pe. João, capelão de São João del-Rei, ser acusado de "andar amancebado com uma viúva, chamada Escolástica, de casta da terra". Era notório ter alguns filhos, dentre os quais um criava "com o título de enjeitado".11 Havia ainda um rol de padres, que "vagando pelos matos", cometia "desatinos". O Pe. Antônio Soares, em Barbacena, havia anos que estava amancebado com a "bastarda forra Maria Pais", com quem tinha filhos, vivendo nas partes do Sapucaí, "apartado no mato, parecendo mais bruto que clérigo". Preso, foi remetido ao Rio de Janeiro. ${ }^{12}$

Outros foram delatados por descumprirem suas obrigações. Era o próprio Pe. Francisco Fernandes Guimarães, coadjutor na freguesia de Santo Antônio de São José, hoje Tiradentes, quem era obrigado a reconhecer as faltas do Vigário Ferraz, por ter deixado morrer "Braz da Costa, carijó, sem administrar os devidos sacramentos". Costumava também proceder ao "batismo de adultos sem os examinar" se estavam "bem instruídos nas coisas da fé" e tampouco examinava "da doutrina cristã as pessoas que vêm a satisfazer aos preceitos da quaresma". Admitiu, na quaresma daquele ano, a vários casados ausentes de sua mulher, como a Francisco Rangel, "que vivia com uma carijó bastarda", em São José.13 Afinal, ele próprio andava amancebado com "uma viúva chamada Escolástica com casta da terra", com quem tinha "alguns filhos", sendo que um deles estava "criando com o título de enjeitado". Ao serem denunciados, foram condenados não por concubinato, mas por "outras culpas", como consta do rol dos culpados.14

10 Sobre a vida desregrada do clero, ver VILLALTA, Luiz Carlos. A "torpeza Diversificada dos Vícios": celibato, concubinato e casamento no mundo dos letrados de Minas Gerais (1748-1801). São Paulo, 1993. Dissertação (Mestrado em História) - Faculdade de Filosofia e Ciências Humanas, Universidade de São Paulo.

11 ACM, Livro R 18, Devassa (1756-1757), p. 119.

12 ACM, Devassa (1738), p. 146, 148, 148v.

13 ACM, Livro n. 31, Devassa (1733), p. 125v.

14 ACM, Livro R 18, Devassa 1756-1757, p. 119. 
Apesar de tantas reclamações dos paroquianos, a Igreja, muitas vezes, favoreceu o descrédito das acusações de muitos fiéis - pouco afeitos à incoerência do discurso religioso e sua prática - fazendo vistas grossas à vida desregrada e indisciplinada do clero. Por isso, alguns até chegaram às raias da indignação. A descompostura de Inácio Dias da Silva foi um bom exemplo. Na Capela de Santo Antônio de Lagoa Dourada, durante uma missa conventual, em vinte de julho de 1749, entrou armado e se levantou "a falar descompostamente contra o estado eclesiástico e a religião cristã, que os bispos são uns ladrões". Acusado de ser "facinoroso e valentão", ainda gabava-se de "abrir a cabeça em cruz de um clérigo". Pelos seus "excessos" foi condenado à excomunhão maior e contra ele se passou a declaratória de humildemente pedir perdão publicamente em um domingo. Além disso, teve de pagar uma libra de ouro em obras do Seminário de Mariana e cumprir seis meses de degredo fora da comarca. ${ }^{15}$ Talvez, por isso mesmo, quatro carijós tenham se negado a cumprir a desobriga, por ocasião da quaresma, com o Pe. Antônio Mendes. Era ele quem havia desobrigado dois clérigos concubinados. Por tamanho acinte, foram expostas "na porta da Igreja como excomungadas". 16

Mesmo assim a Igreja foi extremamente vigilante e severa com os paroquianos, cuidando dos deslizes e lapsos de índios coloniais. Não faltando denúncias de toda a natureza contra eles, foram acusados por vários motivos.

Quadro 3

Motivos das denúncias nas devassas / quantidade (1721-1800)

\begin{tabular}{|l|c|}
\hline \multicolumn{1}{|c|}{ Motivos } & Quantidade \\
\hline Bebedeira & 2 \\
\hline Alcouce/Consentimento & 13 \\
\hline Comunicação/Trato ilícito & 40 \\
\hline Concubinato & 660 \\
\hline Curandeirismo/Feitiçaria & 9 \\
\hline Incesto & 11 \\
\hline Meretrício & 31 \\
\hline Meretrício/concubinato & 1 \\
\hline Total & 767 \\
\hline
\end{tabular}

Fonte: ACM, Devassas Eclesiásticas (1721-1800).

ACM, n. 4550, 1749

6 ACM, livro n. 33, Z1, Devassa, (1738), p. 146. 
Alguns foram condenados pela vida descomedida, como José de Almeida, bastardo, morador na freguesia de São João del-Rei, acusado de "freqüentemente se embebedar" 17 e por se envolver em "bulhas e pendências". ${ }^{18}$ Outros foram acusados por feitiçaria, adivinhações e embustes. Em Baependi, Antônio Gomes, bastardo, era penalizado por curar animais "com palavras supersticiosas". ${ }^{19}$ Pelo mesmo crime, era punido João da Veiga, homem bastardo. ${ }^{20}$ Em 1759, em Airuoca, uma carijó era com ervas". Domingos Leme, "bastardo forro" e "soldado do mato", em 1734, era condenado "por usar de malefícios para que as mulheres o procurem" e essas "fazem excessos acusada porque "curava pelo dito". Uma mulher, chamada [Paula?] bastarda, sem domicílio certo, era tachada de feiticeira. ${ }^{21}$ Em 1763, outra "índia" era penalizada por "fazer cabaça onde tem colocado coisas que parecem diabólicas". $22 \mathrm{Na}$ Vila de São João del-Rei, em 1763, Mariana Custódia era "enfamada de feiticeira e com seus feitiços costuma matar". 23

Das 9 denúncias referentes à feitiçaria e curandeirismo, promovidas pelas devassas em Minas, apenas localizamos dois processos de feitiçaria que estão depositados no Arquivo da Cúria de Mariana. ${ }^{24}$ Um deles são os notáveis autos de Paula Almeida, bastarda, e Antônio Martins Pereira, presos e condenados à excomunhão maior, em 1765, com penitência pública na Igreja, seguidos de três anos de degredo do bispado, tudo "por ofensa à religião cristã". Isso tudo acrescido das custas de vinte mil cruzados. A razão alegada era terem eles, em primeiro lugar, cometido "incesto, por cognação espiritual", já que estavam ligados pelo compa-

17 ACM, Livro R 18, Devassa, (1756-1757), p. 124.

18 ACM, Livro n. 26, Devassa (1727-1748), p. 92-95.

19 ACM, Livro R 18, Devassa, (1756-1757), p. 148; ACM, Livro 26, Devassa, (1727-1748), p. 142.

20 ACM, Livro R 18, Devassa (1756-1757), p. 159.

21 ACM, Livro n.46 Devassa (1763-1764), p. 17; Livro R18, Devassa 1756-1757, p.151.

22 ACM, Livro R 18 (testamento), Devassa (1756-1757), p. 151. A feitiçaria era rigorosamente punida com o degredo para a África, excomunhão e penitência pública. Constituições do Arcebispado da Bahia, Livro 5, Tit. III-VI, p. 335-341.

23 ACM, Livro n.46 Devassa (1763-1764), p. 12v

24 Em Minas Gerais, no total de 205 casos estudados por Laura de Mello e Souza, a autora apresentou 2 casos de "benzedura", 16 de "tensões várias", 10 de "tensões entre senhor e escravo", 24 de "pacto e invocação de demônios", 9 de "calundus", todos envolvendo população "preta ou branca". No quadro por região, para o período de 1775-1800, indicou 4 casos, em Minas Gerais, envolvendo população "mestiça". Como vimos, essas práticas estiveram presentes entre os índios coloniais, apesar de muitos não terem se constituído em processos. SOUZA, Laura de Mello de. O Diabo e a terra de Santa Cruz: feitiçaria e religiosidade popular no Brasil colonial. São Paulo: Companhia das Letras. 1986, p. 384, 385, 385. 
drio, mas, sobretudo, por causa das práticas de "feitiçaria ou embustices" quando "cortaram o cabelo de uma negra benguela e jogaram no córrego onde se fez um redemoinho". Na enxovia da cadeia de São João del-Rei, Antônio, "roceiro de grande fábrica", encontrava-se bastante enfermo, "com queixa de risco de vida". $\mathrm{O}$ cirurgião aprovado pela Sua Majestade, Jerônimo de Paiva, apresentou seu diagnóstico: declarava que o preso padecia de uma "[morbosidade?] caquética", com o "pulso freqüente desordenado", "elevação do ventre e grande ansiedade, com fedor e outros sintomas de que no sangue há embaraços por cujo motivo não faz sua circulação". A "inquietação de ânimo" se justificava também pelas dores causadas por um tombo que "há poucos meses" lhe "quebrou uma perna" e, por essa razão, recomendava a aplicação de "alguns alívios" que não podiam "comodamente fazer por se achar fora de sua casa". Na defesa de Paula bastarda entrou o seu marido, queixoso da "[panelada?] armada" pelo próprio Antônio que persuadiu o reverendo José Álvares que a "denunciada era feiticeira". Era Paula também quem se dizia presa na cadeia "por falsa denunciação que deram pessoas inimigas" e, por causa de seus "achaques", rogava pelo privilégio de poder se curar fora da cadeia, em casa de "gente casada". As lamúrias pouco valeram e os dois amargaram as moléstias e doenças que contraíram durante os dois anos que permaneceram na enxovia. ${ }^{25}$

A relação dos colonos com as índias era patente. Não faltou ocasião em que alguns se aproveitassem da situação de desamparo das índias para se beneficiarem, fazendo casa de alcouce. ${ }^{26}$ Muitos até compravam índias para esse fim, acusavam alguns delatores. Assim, em Borda do Campo, Luiz de Barros e seu filho Manoel de Barros foram notificados por consentirem que uma "carijó" estivesse "vivendo de usar mal de si, inquietando-se sem pejo nem temor de Deus". Muitos visitantes com o "fim da ofensa de Deus se agregam" a sua casa. O visitador mandou prontamente "cessar o escândalo", exigindo o "recato de sua casa e famílias". ${ }^{27}$ Em 1757, Perpétua Marques, bastarda, solteira, moradora na vila de São João del-Rei, no distrito de Santa Rita, fazia termo de "meretriz pública". O mesmo se deu com Rita Furquim, bastarda, solteira.28 No "sítio do Tejuco",

25 ACM, JE, n. 4457, (1765)

26 Na Minas setecentista, casas de alcouce eram as vendas, as tabernas, com seus proprietários fazendo as vezes de alcoviteiros ou rufiões. Podiam também ser os "domicílios de mulheres pobres e forras e mais raramente as senzalas de escravos". Figueiredo, O avesso da memória..., p. 88-90.

27 ACM, Livro n. 3, Devassa (1730), v. 1, p. 11v.

28 ACM, Livro n. 21, Devassa (1752-1760), p. 24 
também em São João del-Rei, Brígida, carijó, era acusada de meretrício. ${ }^{29}$ Em Bonsucesso, era "público e notório" a presença de duas bastardas "meretrizes escandalosas". ${ }^{30}$ Uma viúva, que morava nas redondezas de Alagoinha, freguesia dos Carijós, chamada Antônia, era denunciada com suas duas filhas, Joana e Teodora. Juntamente com as tais filhas "são mal procedidas e públicas meretrizes admitindo homens em sua casa para fins torpes e desonestos". ${ }^{31}$

Não é difícil entender então por que algumas mulheres indígenas acabaram se entregando ao meretrício nessas casas de alcouce. ${ }^{32}$ Há de se considerar, contudo, o sentido de se prostituir na Minas setecentista. Muitos autores mostraram como as mulheres, marginalizadas em uma sociedade misógina, baseada em um sistema econômico marcado pelo trabalho escravo e masculino, encontraram alternativas de sobrevivência, seja atuando no comércio ambulante, nas vendas, nos tabuleiros, seja nos afazeres domésticos ou mesmo na prostituição. ${ }^{33}$ Com o tipo de sociedade que se formou em Minas, onde o itinerância e o absenteísmo masculino primaram, a Igreja condenava como "imoral" a iniciativa de mulheres que encabeçavam os domicílios, rotulando-as de prostitutas, porque "implicava a troca de papéis, assumindo as mulheres papéis masculinos e quebrandose na prática a divisão de tarefas entre os sexos", como bem lembra Torres-Londoño. ${ }^{34}$

Para a Vila de São João del-Rei e distritos, os fogos chefiados por mulheres não-brancas o eram, na maioria dos casos, por solteiras $(53,47 \%)$, viúvas $(34,89 \%)$ e apenas uma pequena parcela de casadas (11,64\%). Esses dados indicam, como considera Sílvia Brügger, "que era na área urbana que as mulheres solteiras encontravam meio mais propício para garantirem sua sobrevivência ou que, ali, talvez o casamento fosse menos necessário para seus projetos de vida". ${ }^{35}$ Em um levantamento para Ouro Preto, de 1804, Donald Ramos mostrou que $45 \%$ das famílias da vila eram susten-

ACM, Livro n. 44, Z9, Devassa (1759-1760), p. 134

ACM, Livro Z11, Devassa (1763-1764), p. 12v.

31 ACM, Livro n. 39, Devassa (1750-1753), p. 67.

32 Apesar de ser considerado grave, o meretrício não era considerado crime e era punido como um comportamento desregrado, por meio da prisão ou degredo, somada à pena pecuniária. Constituições do Arcebispado da Bahia, Livro V, Tít. XXV, p. 371.

33 SOUZA, Laura de Mello e. Desclassificados do Ouro. A pobreza mineira no século XVIII. Rio de Janeiro: Graal, 1982, p. 180 e seguintes. PAIVA, Eduardo França. Escravos e libertos nas Minas Gerais do século XVIII: estratégias de resistência através dos testamentos. Belo Horizonte, 1993. Dissertação (Mestrado em História) - Faculdade de Filosofia e Ciências Humanas, Universidade Federal de Minas Gerais.

34 Torres-Londoño, loc. cit., p. 98.

35 BRUGGER, Sílvia M. Jardim. Minas patriarcal. Família e sociedade (São João del-Rei, séculos XVIII e XIX). 2002. Tese (Doutorado) - UFF, Niterói, 2002. p. 97. 
tadas por mulheres. Situação explicada em boa parte porque as mulheres compunham $53,3 \%$ do total da população livre. Por isso, muitas mulheres, à custa de seu trabalho - seja na vendas, costurando, vendendo comidas nas ruas, lavando roupa ou produzindo gêneros alimentícios em pequenos sítios - eram as mantenedoras de seus lares. ${ }^{36} \mathrm{O}$ enorme fluxo de homens, nada contrabalançado com a escassez de mulheres, favoreceu esse tipo de conduta, por diversas vezes condenada em bandos que propunham casas de correção para mulheres prevaricadoras. O indiciamento de mulheres tidas como "mal-procedidas" revela a rigidez da ótica da Visitação, incapaz de se dar conta da especificidade dessa formação social. ${ }^{37} \mathrm{E}$ as índias coloniais não escapuliram a essa lógica e aos rigores da Igreja, já que, muitas vezes, o preço de sua autonomia a obrigação de cuidar de si - foi o caminho, muitas vezes, do meretrício.

\section{Vidas concubinas, vidas paralelas}

Saltam aos olhos nas delações as relações matizadas por concubinato, às vezes, com indícios de coabitação, cujos atores também foram os índios coloniais. Como vimos, das 767 denúncias, 660 referiam-se ao concubinato. Grassando solto por Minas como um rastilho, maculava a política da Igreja, defensora incondicional do casamento como base das famílias. Como lembra Laura de Mello e Souza, se os conflitos urbanos, a disseminação dos mestiços e a ameaça dos quilombos eram prementes, "a falta de laços familiares da população foi outro fantasma que perseguiu as autoridades", tornando-se o pilar também da ação do Estado.38

Seguramente o crime mais punido foi o concubinato, união livre sem a sacramentalização da Igreja, responsável pela avalanche das delações. O concubinato constituiu-se, assim, na principal relação ilícita que muitos índios coloniais ousaram ostentar publicamente na Minas Gerais. De fato, foi o alvo fácil por ter sido um comportamento corriqueiro entre os índios coloniais - como de resto para boa parte dos colonos. ${ }^{39}$

36 RAMOS, Donald. A mulher e a família em Vila Rica de Outro Preto: 1754-1838. História e população. Estudos sobre a América Latina. São Paulo: Abep, 1990. p. 155-163.

37 SOUZA, Laura de Mello e, loc. cit., p. 181, 182.

38 SOUZA, Laura de Mello e Souza, loc. cit., p. 113.

39 Luciano Figueiredo menciona que $85 \%$ do total dos culpados nas devassas em Minas Gerais eram acusados de concubinato. Figueiredo, loc. cit., p. 195. 
As análises sobre as relações familiares em Minas reconhecem praticamente como consensual o predomínio das relações nãosancionadas pela Igreja, refletidas em elevados índices de nascimentos ilegítimos.40 Para São João del-Rei, os índices de legitimidade, ao longo do século XVIII e primeira metade do séc. XIX, oscilaram entre 50 e $60 \%$ dos batizandos, atingindo seu ponto máximo, entre 1781 e 1790, com 61,56\%. Para Sílvia Brügger, a leitura destes índices parece "comprovar a grande disseminação, nesta sociedade, das relações extraconjugais, embora fossem sempre minoritários os nascimentos provenientes destas uniões em comparação com aqueles gerados por casais legitimamente casados". ${ }^{41}$ O número maciço das denúncias (660) por concubinato também é um indicativo dessa situação.

Após serem denunciados por concubinato, os acusados eram obrigados a comparecer junto à mesa para serem publicamente admoestados. Ali mesmo assinavam um termo de "emenda", comprometendo-se a abandonar sua vida "libidinosa e dissoluta", sob o risco de "severamente serem castigados". 42 As reincidências eram punidas com a separação, a prisão e o degredo, conforme a gravidade do delito.

Não se contentando com as penas de cunho espiritual, o Juízo Eclesiástico acrescentava ainda as "penas pecuniárias", para que "os façam temer, emendar e tirar do pecado". ${ }^{43}$ Não é demais lembrar que esta prescrição não foi letra morta para a Minas colonial durante as Visitas. Tendo a Igreja exigido a prova de coabitação para a imposição das penas, os padres extorquiam os valores pecuniários daqueles licenciosos que confessavam seu pecado. Ainda que os valores tenham sido considerados ínfimos, boa parcela do

$40 \mathrm{O}$ índice de ilegitimidade demonstra a vigência de relações extra-conjugais. Ver sobre isso, RAMOS, Donald, A mulher e a família em Vila Rica. A Estrutura demográfica de Vila Rica às vésperas da Inconfidência. Anuário do Museu da Inconfidência, Ouro Preto, 1978; COSTA, Iraci del Nero da. Vila Rica: população (1719-1826). São Paulo: IPE/USP, 1979; COSTA, Iraci del Nero da. Populações mineiras: sobre a estrutura populacional de alguns núcleos mineiros no alvorecer do século XIX. São Paulo: IPE/FIPE, 1981.

41 Brugger, loc. cit., p. 90.

42 Procurando definir o pecado do concubinato, o texto tridentino setecentista entendia a "coabitação" e a "publicidade" como as suas principais características. A estas duas, as Constituições primeiras do Arcebispado do Bahia, que tratavam especificamente do mundo colonial, acrescentavam a longevidade das relações sexuais ilícitas. Portanto, o concubinato se diferenciava da "incontinência sexual", fornicação ocasional e com parceiros diferentes, recebendo, por isso mesmo, uma punição mais severa. Constituições primeiras do Arcebispado da Bahia, Livro 5, Tít. 22, par. 979; tit. 23, par. 993.

43 Constituições primeiras do Arcebispado da Bahia, Livro 5, tit. 23, par. 979. 
gentio, desprovida e empobrecida, teve que pagar pelos termos de admoestação. Quase sempre os parceiros não escapuliram à avareza da igreja, condenados que eram a pagar pelas despesas da cúmplice indígena "por ser causa de sua culpa". E quando estavam na condição de administrados, e o concubinato era com um escravo, cabia ao seu senhor o pagamento pecuniário, que também era responsabilizado pelas infrações. Das 767 denúncias referentes aos índios coloniais, somente temos 201 termos de culpa. Destes termos, $140(69,6 \%)$ pagaram as custas.

Pegos nas malhas da visita pelo seu envolvimento com as índias, muitos eram obrigados a expulsar sua concubina de casa. Manoel Queiroz, da freguesia de Borda do Campo, foi culpado por "andar amigado com uma carijó, chamada Eugênia". Para evitar a pena, foi obrigado a lançá-la "fora" no prazo de 24 horas. Prometia fazê-lo "voluntariamente" e para provar sua boa vontade se sujeitava à pena de excomunhão à sua revelia. Mesmo assim não deixava de se precaver, astuto e matreiro, requerendo de antemão "lhe fosse cominada" no caso de não cumprir a promessa. ${ }^{44}$ Manoel sabia bem que era muito difícil escapulir às denúncias e muito mais de sujeitar-se às imposições da Igreja.

Tentando inibir a ousadia dos senhores, que publicamente assumiam sua "lascívia", a Igreja policiava o contato entre os condenados. Em São João del-Rei, Verônica, bastarda, foi condenada com seu senhor, Salvador Cardoso. O visitador mandou, debaixo de "excomunhão maior e de ser com rigor censurada", que ela saísse de casa "em depósito" para a casa de Sebastião Gonçalves Chaves, o qual se obrigou "a tomar conta dela". Quanto a Salvador Cardoso, estava obrigado a "procurar casamento" ou "vender" Verônica, "para não desinquietá-la". ${ }^{45}$

Nem sempre expulsar a amásia de casa bastou aos rigores da Igreja. Em Airuoca, Domingos de Oliveira Leitão, por incorrer no mesmo crime com Escolástica, mulher bastarda, além de ser condenado em seis mil réis e nas custas dos termos, também se viu obrigado a pô-la "fora da freguesia". ${ }^{46}$ Mais grave ainda foi o caso de João Gonçalves. Morador em Borda do "Campo, era culpado "por andar amigado com Mônica carijó", já denunciado em duas visitas passadas e, por essa razão, "asperamente repreendido". ${ }^{47} \AA$ vista de sua pertinácia, foi condenado a dois anos de degredo para

44 ACM, Livro n. 25, Devassa (1726-1743), p. 9.

45 ACM, Livro n. 3, Devassa (1730), v. 1, p. 80, 81v.

46 ACM, Livro n. 3, Devassa (1730), v. 1, p. 43, 43v.

47 ACM, Livro n. 25, Devassa (1726-1743), p. 4. 
a Ilha de São Tomé e ao pagamento de vinte oitavas de ouro para a Bula, Sé e Meirinho, "no caso em que se não apartar" definitivamente de sua concubina. 48

Alguns, por isso mesmo, tentavam negar as delações, certamente temerosos das penalidades. Na freguesia dos Carijós, José de Oliveira recusava-se a admitir a culpa "por não ter trato ilícito algum" com Conceição, carijó, ainda que aceitasse a repreensão. Prontificava-se em "colocar fora a carijó" em 24 horas "somente para evitar o escândalo". ${ }^{49}$ Outras vezes, os denunciados não concordavam com os termos das denúncias. Mas pouco podiam fazer na prática. Em Prados, José Ribeiro Marins afirmava que era "inocente da culpa". Por não ter "delinqüido", estava "se livrando no Juízo Secular", onde contrapusera um agravo ao Reverendo Visitador. Mas poucos dias depois, era já derrotado. Foi, assim, obrigado a contradizer-se, reconhecendo "que estava pela culpa", aceitando a "admoestação e prometendo emenda" de "se sujeitar à Igreja e a tudo o que se lhe determinasse". 50

Não é sem razão que muitos infratores procurassem acobertar a situação ilícita. Muito comum foi dissimular as relações ilegítimas, ausentando-se por ocasião das visitas. Na freguesia de Prados, Paulo Colaso, na quaresma, "teve fora de casa" sua concubina Margarida, bastarda, mas logo depois "a tornou a recolher com o mesmo escândalo. 51

Alguns burlavam o ramerrão eclesiástico. Domingos Barbosa estava amancebado com uma carijó, "que diziam ser escrava de um homem" do Rio das Mortes. O padre negava-se à "desobriga" porque no ano anterior, Domingos já havia sido "corrigido" e, apesar disso, retirara-se para as "perapetingas" onde insistia em mantê-la em casa. Atendendo aos apelos e certamente às ameaças do vigário, Domingos, então, expulsou Catarina carijó, mas tão logo foi admitido aos sacramentos, "tornou a recolhê-la e com ela anda amancebado.52 Isso demonstra bem que muitos, quando tinham oportunidade, faziam ouvidos moucos à arenga dos vigários.

A conivência dos amigos mais próximos ou dos familiares parece ter sido uma boa estratégia para esquivar-se das visitas. Apesar de as visitas eclesiásticas procurarem "enfraquecer a solidariedade" na freguesia, como considerou Torres-Londoño, ao selecionarem suas testemunhas, nem sempre seu intento foi efi-

ACM, Livro n. 25, Devassa (1726-1743), p. 4.

ACM, Livro n. 25, Devassa (1726-1743), p. 11

50 ACM, Livro n. 6, Devassa (1730-1731), p. 26.

51 ACM, Livro n. 28, Devassa (1730-1731), p. 49

52 ACM, Livro n. 30, Devassa (1733), p. 49v. 
caz. ${ }^{33}$ Alguns pais também foram coniventes com a "libertinagem" dos filhos. Jerônimo Sardinha, em Prados, permitia que seu filho Antônio andasse com uma bastarda, Isabel, em sua própria casa. ${ }^{54}$ Em Carrancas, José andava com outra bastarda, por nome Gertrudes, e Domingos Garcia, seu pai, foi incriminado por ser "consentidor do dito concubinato". 55 Para Teresa Dias, carijó, mãe de Rita, concubina de Sebastião de Leal Quaresma, moradores na freguesia dos Prados, não houve escapatória. Denunciada como "consentidora", foi condenada e presa. ${ }^{56}$ Essa colaboração mútua pode também ser entendida porque havia uma rede de denúncias em que delatores também eram delatados. E não faltou caso em que a denúncia dizia respeito ao mesmo pecado. Vicente Luís, solteiro, natural de São Paulo, que vivia de sua roça, aos 30 anos, acusava Pedro Fernandes de andar com uma carijó, Esmênia. Mas o próprio Vicente não podia furtar-se, pois também seria denunciado por estar amasiado com outra índia, Luzia. ${ }^{7}$

Não faltou também quem recorresse a outros métodos. João Lobo, da freguesia de Borda do Campo, gabava-se entre os amigos de já ter reservado em sua algibeira "ouro para a visita", dando com isto a entender que "fazia gala do seu pecado". Escandalizando, com sua dissolução e fama, andava concubinado com Teresa Lopes, curiboca, há dois anos. ${ }^{58}$ No ano anterior, contava que, por ocasião da desobriga da quaresma, o Vigário "obrigou a lançar a dita concubina, mas que em seu lugar havia de ir logo buscar duas para casa". ${ }^{9} \mathrm{~A}$ verdade é que não faltaram padres que cobravam para atender o gosto dos paroquianos. 60

Esses depoimentos expõem visceralmente a condição da mulher indígena na Minas colonial, as mais das vezes, enredadas pelo desprezo e discriminação da população branca. Pelas línguas ferinas dos delatores, destilavam acusações de toda sorte sobre as relações extraconjugais. Reduzidas à condição de "índia", "bastarda" ou "carijó", no propósito de identificar seu comportamento como próprio de sua condição, em várias denúncias sequer o no-

53 TORRES-LONDOÑO, Fernando, loc. cit., p. 146.

54 ACM, Livro n. 28, Devassa (1730-1731), p. 68v.

55 ACM, Livro R 18 (testamento), Devassa (1756-1757), p. 124.

56 ACM, Livro R 18 (testamento), Devassa (1756-1757), p. 183v

57 ACM, Livro n. 28, Devassa (1730-1731), p. 79v. Há várias acusações recíprocas, como Bento Manoel e José Roiz Chaves, de se acusarem de estarem de "portas adentro" com carijós. ACM, Livro n. 23, Devassa (1722-1723), (testemunha), p. 171.

58 ACM, Livro n. 31, Devassa (1733), p. 60v.

59 ACM, Livro n. 31, Devassa (1733), p. 61.

$60 \mathrm{ACM}, \mathrm{JE}$, n. 4551, (1771). João Alves reclama do padre que lhe prometera dinheiro para se casar com Rosa. 
me aparece. É que a má vontade de muitos se explica, na verdade, pelo comprometimento que essas ligações causavam aos casamentos. Seja pelo absenteísmo dos homens nos lares, seja pela reclusão das mulheres brancas na corte, pululavam em toda a Minas Gerais relações extraconjugais com as índias e o adultério foi seu maior tormento. ${ }^{61}$ Era o verdadeiro "relaxamento da vigilância dos sentidos", constituindo-se como uma violação do contrato matrimonial, "roubo" da honra e do patrimônio da família do qual o marido era o titular, conforme condenava o discurso eclesiástico. Daí a preocupação de que o "ajuntamento carnal" fosse público porque, neste caso, o adultério ultrapassava a fronteira da luxúria e trazia sérias implicações sobre o direito ao patrimônio, esbulhando a "fazenda" do marido e dos herdeiros legítimos. ${ }^{62}$ Por isso, a traição era facilmente associada à fornicação com prostitutas, escravas ou mulheres recrutadas nas camadas mais pobres, atrelando as mulheres indígenas a essa imagem, com o intuito de desqualificar e desacreditar tais envolvimentos.

\section{Considerações finais}

O que podemos inferir da análise das devassas é que, a despeito das denúncias de uma vida coroada por "escândalos", nas vilas de Minas Gerais setecentista, a Igreja cumpria o papel de enfatizar um discurso desqualificador dos indígenas. Parte de sua argumentação detratora se baseava nas raízes do "gentio da terra", que, aos seus olhos, se constituíam no principal motivo, senão na principal justificativa de tamanha "devassidão e promiscuidade". Nesse sentido, a Igreja naturalizava um discurso de que a origem autóctone imporia um certo comportamento, maculado pela "libidinagem e improbidade", disseminando tal idéia por todos os recantos de Minas. Reprovando essa conduta e imputando esse comportamento "lascivo" àqueles de origem nativa, procurava-se escamotear o cotidiano colonial dos índios, imersos em uma vivência bastante distante dos padrões ditados pelo Juízo Eclesiásti$\mathrm{co}, \mathrm{o}$ tentáculo inquisidor tentáculo inquisidor a Igreja.

61 A população feminina era inferior a masculina, com um abaixo índice de mulheres brancas, favorecendo às uniões ilícitas, na maioria das vezes, entre brancos e mulatas ou negras. BOXER, Charles. A idade de ouro no Brasil. São Paulo: Nacional, 1969, p. 165.

62 ALMEIDA, Angela Mendes. O gosto pelo pecado. Rio de Janeiro: Rocco, 1992. p. 98. 


\section{Referências}

ALMEIDA, Angela Mendes. O gosto pelo pecado. Rio de Janeiro: Rocco, 1992.

BOSCHI, Caio César. As visitas diocesanas e a inquisição na colônia. Revista Brasileira de História, São Paulo, v. 7, n. 14, 1987.

BOXER, Charles. A idade de ouro no Brasil. São Paulo: Nacional, 1969.

BRUGGER, Sílvia M. Jardim. Minas patriarcal. Família e sociedade (São João del-Rei, séculos XVIII e XIX). Niterói, 2002. Tese (Doutorado em História) Universidade Federal Fluminense.

COSTA, Iraci del Nero da. Vila Rica: população (1719-1826). São Paulo: IPE/USP, 1979.

. Populações mineiras: sobre a estrutura populacional de alguns núcleos mineiros no alvorecer do século XIX. São Paulo: IPE/FIPE, 1981.

FARIA, Sheila de Castro. Colônia em movimento. Fortuna e família no cotidiano colonial. Rio de Janeiro: Nova Fronteira, 1998.

FIGUEIREDO, Luciano Raposo de A. Barrocas famílias: vida familiar em Minas Gerais no século XVIII. São Paulo: Hucitec, 1997.

; RAPOSO, Luciano A. Segredos de Mariana: pesquisando a inquisição mineira. Acervo, Rio de Janeiro, v. 2, n. 2, jul.-dez. 1987, p. 1-34.

COSTA, Iracy Del Nero da. Devassas nas Minas Gerais do crime à punição. Anuário de Estudios Americanos, Sevilha, tomo 39, 1982.

RAMOS, Donald. A mulher e a família em Vila Rica de Outro Preto: 17541838. História e população. Estudos sobre a América Latina. São Paulo: Abep, 1990.

SOUZA, Laura de Mello e. As devassas eclesiásticas da Arquidiocese de Mariana para a história das mentalidades. Anais do Museu Paulista, v. 33, 1984.

. O Diabo e a terra de Santa Cruz: feitiçaria e religiosidade popular no Brasil colonial. São Paulo: Companhia das Letras. 1986.

. Desclassificados do ouro. A pobreza mineira no século XVIII. Rio de Janeiro: Graal, 1982.

TORRES-LONDOÑO, Fernando. A outra família. Concubinato, igreja e escândalo na colônia. São Paulo: Loyola, 1999.

VILLALTA, Luiz Carlos. A "torpeza diversificada dos vícios": celibato, concubinato e casamento no mundo dos letrados de Minas Gerais (1748-1801). São Paulo, 1993. Dissertação (Mestrado em História) - Faculdade de Filosofia, Letras e Ciências Humanas, Universidade de São Paulo. 